\title{
HEART ROTS IN RELATION TO THE MANAGEMENT OF SPRUCE IN ALBERTA ${ }^{1}$
}

\author{
By V. J. NORDIN ${ }^{2}$
}

\section{ABSTRACT}

Some of the factors influencing the progress of decay and the estimation and prevention of decay in living trees are considered in relation to the forest management of spruce in Alberta.

\section{INTRODUCTION}

There are various types of diseases that affect spruce throughout its life from the time the seed germinates to the time that the tree completes its natural life span. These diseases are physiogenic or pathogenic in origin, or they may be the result of an inter-relationship of both these categories.

Some physiogenic diseases that affect spruce are frost, as exhibited by the discoloration in foliage and by frost cracks which may provide areas of infection for heart rot fungi; chlorosis, as evidenced by unhealthy foliage caused by unfavorable environment or soil conditions; flood injury, causing local mortality and resulting from beaver dams; hail damage; and lightning, causing complete or partial shattering of the tree or injury through scarring.

Examples of pathogenic diseases are "damping-off" of seedlings; cankers; stains; root rots and trunk rots; snow blight; cone rusts; rust and needle cast diseases of the foliage; and damage caused by dwarf mistletoes. A number of diseases, such as the burls or tumors on spruce, are of unknown origin.

The foregoing types of diseases are of varying significance, depending frequently upon the age and composition of the stand as further conditioned by site and stand history. Undoubtedly, the most important disease affecting the mature and overmature timber stands of spruce in Alberta, however, is heart rot which occurs in the root and trunk regions of the tree. The discussion following will deal with this disease as it influences the management and utilization of spruce in this region.

\section{Factors Influencing the Progress of Decay in Living Trees of Spruce}

There are four dominant factors influencing the progress of decay in living trees: age, site, stand history, and stand composition.

An established principle for heart rots in trees is that the incidence and volume of decay increase with increasing age. Spruce in Alberta is no exception. In a dissection analysis of 419 subalpine spruce Etheridge (3) found the in-

\footnotetext{
'Manuscript received November 29, 1955. Contribution No. 265 from the Forest Biology Division, Science Service, Department of Agriculture, Ottawa, Canada. Adapted from a paper presented to the membership of the Rocky Mountain Section, Canadian Institute of Forestry, at Red Deer, Alberta, January 22, 1955.

'Officer-in-Charge, Forest Pathology Laboratory, Calgary, Alberta. Biographical reference, The Forestry Chronicle, Vol. 30:299.
} 
cidence of decay to be $0 \%$ at $61-100$ years; $17 \%$ at $101-140$ years; $30 \%$ at $141-$ 180 years; $60 \%$ at $221-260$ years; and $100 \%$ in trees $301-340$ years. These figures are average and marked variations may occur in specific stands. Further, this incidence is based on decay visible at stump height so that examinations of root systems undoubtedly would lower the initial age of infection.

On a board foot volume basis, the percentage of decay increases from $9.9 \%$ at 120 years, to $15.5 \%$ at 190 years, and to $26.2 \%$ at 310 years. The average pathological rotation age as indicated by the net mean annual increment occurs at 190 years (3). Again, this is an average figure for subalpine spruce stands and this age can be expected to vary, depending upon differences in site and forest type. It must be remembered also that only survival trees are examined in computing this age and that mortality throughout the life of the stand is not considered. On a stand basis, therefore, the pathological rotation age and initial age of infection would be reduced. For large scale inventory purposes where a range of sites and types is sampled, the foregoing figures are satisfactory.

At present, decay data for boreal spruce are not comparable to those available for subalpine spruce, although investigations are in progress to obtain this information. On the basis of a sample of trees at Slave Lake, Fawcett Lake, and Calling Lake (2), the percentage of decay ranged from $0 \%$ at 60 years to a high of $7.0 \%$ at 160 years. The volumes of decay are much higher in boreal spruce than in subalpine spruce, but the percentage of decay at comparable ages is much lower because the average gross merchantable volumes are generally four times as great as those in subalpine trees of the same age. These points, emphasizing the importance to forest management of regional variations in decay, are brought out in Table $I$.

\section{TABLE 1}

The Relationships Between Age, Gross Merchantable Volume, Decay Volume, and the Percentage of Decay in Boreal and Subalpine Spruce in Alberta ${ }^{1}$

\begin{tabular}{|c|c|c|c|c|c|c|}
\hline \multirow[b]{2}{*}{ Age } & \multicolumn{3}{|c|}{ Boreal Spruce } & \multicolumn{3}{|c|}{ Subalpine Spruce } \\
\hline & $\begin{array}{c}\text { Gross } \\
\text { merchant- } \\
\text { able } \\
\text { volume } \\
\text { (Bd. Ft.) }\end{array}$ & $\begin{array}{c}\text { Decay } \\
\text { volume }\end{array}$ & $\begin{array}{c}\text { Percent- } \\
\text { age of } \\
\text { decay }\end{array}$ & $\begin{array}{c}\text { Gross } \\
\text { merchant- } \\
\text { able } \\
\text { volume } \\
\text { (Bd. Ft.) }\end{array}$ & $\begin{array}{c}\text { Decay } \\
\text { volume }\end{array}$ & $\begin{array}{l}\text { Percent } \\
\text { age of } \\
\text { decay }\end{array}$ \\
\hline 120 & 177 & 8 & 4.5 & 39.5 & 3.9 & 9.9 \\
\hline 130 & 200 & 10 & 5.0 & 48.1 & 5.0 & 10.4 \\
\hline 140 & 219 & 12 & 5.4 & 61.0 & 6.5 & 10.6 \\
\hline 150 & 232 & 14 & 6.0 & 80.5 & 8.4 & 10.4 \\
\hline 160 & 242 & 17 & 7.0 & 94.2 & 10.8 & 11.5 \\
\hline
\end{tabular}

${ }^{1}$ Data adapted from unpublished mimeographed reports $(2,3)$. 
A very useful review of the literature on heart rots in living trees and in relating decay to site, stand history, and stand composition has been presented by Wagener and Davidson (9). There is, however, a scarcity of the latter information for spruce in Alberta. The only data at present available are for subalpine spruce. Briefly, Etheridge (4) has defined "dry" and "moist" sites on the basis of plant criteria and found that a statistically higher percentage of trees was infected on the moist sites in all age classes examined.

Further data relating site factors to the incidence of decay have been collected for subalpine spruce by Etheridge and for boreal spruce by Denyer, and will be presented in mimeographed reports following the completion of the analyses of data.

\section{The Relative Importance of Root Rots and Trunk Rots}

Recent studies of boreal and subalpine spruce in Alberta $(2,3)$ have shown that, for both species, trunk rots account for the greater part of decay in standing trees; approximately $70 \%$ of the total cubic volume of decay (Table II). However, a high occurrence of root rots was recorded; $62 \%$ of the total infections for boreal spruce and $48 \%$ for subalpine spruce (Table II). Root rots are of unevaluated importance in windfall and wind-breakage of spruce. Conceivably, a critical assessment of losses caused by root rots possibly would show the latter to approximate or, in specific instances, exceed the volume losses resulting from trunk rots.

TABLE II

Percentages of Infections and Percentages of Cubic Volume of Root Rots and Trunk Rots in Boreal and Subalpine Spruce in Alberta"

\begin{tabular}{|c|c|c|c|c|}
\hline \multirow[b]{2}{*}{$\begin{array}{c}\text { Type } \\
\text { of } \\
\text { rot }\end{array}$} & \multicolumn{2}{|c|}{ Boreal Spruce } & \multicolumn{2}{|c|}{ Subalpine Spruce } \\
\hline & $\begin{array}{l}\text { Percent- } \\
\text { age of } \\
\text { infections }\end{array}$ & $\begin{array}{c}\text { Percentage } \\
\text { of total } \\
\text { cubic } \\
\text { volume } \\
\text { of decay }\end{array}$ & $\begin{array}{l}\text { Percent- } \\
\text { age of } \\
\text { infections }\end{array}$ & $\begin{array}{c}\text { Percentage } \\
\text { of total } \\
\text { cubic } \\
\text { volume } \\
\text { of decay }\end{array}$ \\
\hline Root Rot & 62 & 29 & 48 & 30 \\
\hline Trunk Rot & 38 & 71 & 52 & 70 \\
\hline Totals & 100 & 100 & 100 & 100 \\
\hline
\end{tabular}

The high incidence of root rot in spruce in Alberta underwrites the danger in selection cuttings contributing to undue windfall and wind-breakage losses and is a factor which deserves careful analysis prior to the formation of specific cutting procedures.

\footnotetext{
${ }^{1}$ Information adapted from unpublished mimeographed reports $(2,3)$.
} 


\section{Estimating Decay in Timber Stands}

The determination of the incidence and volume of decay in timber stands is important to forest agencies requiring information on net volume recovery for specific stands. With a few tree species certain symptoms such as scars, frost cracks, large defective branches, punk knots, resin fiow, and sporophores are useful indices for gauging decay in living trees $(6,10)$. Similar indicators would be very useful in assessing the extent of the "buttermilk" decay caused by Fomes pini (Thore) Lloyd (Figs. 1 and 2 ) because investigations $(2,3)$ have shown that a high percentage of decay in spruce in Alberta is attributable to this one fungus. Punk knots and sporophores are positive indicators for the presence of "buttermilk" decay (1), but these occur too infrequently to be of value in general application for spruce in this region.

The most satisfactory procedure to be recommended for the estimation of decay in spruce on an individual tree basis is to secure decay factors for a given region through a detailed examination of felled trees, correlating decay to age and diameter as conditioned by factors of site, stand history, and stand composition. Some data of this nature directly relevant to forest inventory work, have already been presented $(2,3)$. Etheridge (4) has also found an interesting correlation, which shows promise in estimating hidden decay in specific stands, between the amount of decay in subalpine spruce and the presence of relative numbers of dead trees.

\section{The Control and Prevention of Decay in Spruce}

In forest stands of spruce in Alberta, control of decay within limits of tolerance can only be accomplished concurrently with good management and utilization practices. However, management disciplines to reduce the significance of decay cannot follow a fixed pattern because such methods must be varied according to the characteristics of specific stands. Important considerations are age (e.g., even-aged, all-aged), site, stand history, and stand composition. Direct control measures, such as spraying with fungicides and adjusting the $\mathrm{pH}$ and structure of soil may be adapted to forest nurseries and shade trees, but at present they are economically impractical when considering decay in commercial forests.

An approach to the control of decay suggested by $\mathrm{Bier}^{8}$, which has considerable merit, is to define the management age of utilization as the time when the largest net volume of wood of commercial size per acre is present, or in other words, to determine the productive capacity per acre of the stand at various developmental stages. Naturally, the age of maximum productive capacity per acre would be conditioned by other forest management factors, such as advanced reproduction that may be present in stands. The release of advanced growth by cutting the crop trees may be desirable even though excellent volumes are being produced.

\footnotetext{
Correspondence dated January 24, 1955.
} 
The following measures may contribute to the control of decay in timber stands generally: adequate protection of the forest against injury by fire ( 8 ); conducting a minimum of cuttings in the life of a stand; priority of cutting applied to overmature stands and stands severely damaged by insects, fire, and storms; adjustment of the age of felling and the subsequent logging of a stand for a specific product or products before decay becomes serious; the utilization of trees exhibiting sporophores or wounds such as frost cracks, broken tops, and scars caused by fire, animals, and logging activities; and wherever possible, avoiding careless logging and subsequent injuries to the residual trees.

The "conks" or sporophores of decay fungi in spruce grow mainly on slash and cull logs and occur only sporadically on living trees. Despite this fact, it is advisable to cut down any spruce bearing "conks", e.g. Fomes pini. because recent investigations (5) have demonstrated that the production of fruit bodies is less on felled trees than on similar standing trees, and stops entirely after 10 to 15 years.

A previous paper dealing with lodgepole pine (7) outlined the respective merits of clearcutting and selection cutting from a forest pathological standpoint. Some advantages and disadvantages of these extremes of cutting for spruce are summarized as follows:

\section{A. Advantages of Clearcutting}

1) Even-aged stands may be cut before decay becomes serious.

2) Clearcutting avoids injuries to residual trees which may provide points of entry for decay fungi. The decay hazard will be at a minimum in a stand that is least disturbed by logging.

3) Clearcutting avoids loss of timber through wind-breakage and wind-throw which may result in selectively-cut stands. Once on the ground the trees are subject to early decay.

4) Clearcutting is the only practical treatment for salvaging stands severely injured by insects or dwarf mistletoe, and by hail, wind, or snow storms.

\section{B. Disadvantages of Clearcutting}

Clearcutting in strips leaves overmature trees in the residual strips to continue to decay at an unprofitable rate.

\section{Advantages of Selection Cutting}

1) Selection cutting may provide opportunities to utilize trees exhibiting abnormalities such as scars, cankers, or sporophores.

2) The older recayed age classes in a stand may be given priority of cutting

\section{Disadvantages of Selection Cutting}

1) It is difficult to avoid logging injuries to residual trees. 
2) Wind-breakage and wind-throw, particularly in trees affected by root rot, may result when the stand is opened by selection cuttings and such trees decay quickly on the forest floor.

3) It is frequently impossible to eliminate decayed spruce through selection cuttings because most trees do not show external signs of hidden decay. Further, in even-aged stands of spruce, it is unwise to leave for succeeding cuts the smaller diameter trees that have not yet reached merchantable size, because these trees may be as much or more decayed than the marketable stems. For example, studies in Alberta (3) have revealed that age-decay percentage factors are the same for all trees in an even-aged stand, regardless of size.

At the December 4th, 1954, meeting of the Rocky Mountain Section held at Red Deer, Alberta, it was the majority opinion that the subalpine and boreal spruce stands in this Province are generally even-aged, although other age conditions may occur. From an exclusively forest pathological standpoint, therefore, some form of clearcutting is recommended as one of the major management practices that will prevent decay in even-aged stands of spruce in Alberta, through an adjustment of the time of cutting to an age before decay becomes a limiting factor in net volume recovery.

\section{ACKNOWLEDGMENTS}

The following persons have been most helpful in this presentation: Dr. J. E. Bier, Mr. D. I. Crossley, Mr. D. E. Etheridge, Miss Jean Hewitt, and members of the Biographic Unit.

\section{REFERENCES}

1. BIER, J. E., FOSTER, R. E., and SALISBURY, P. J. 1946. Studies in forest pathology. IV. Decay of Sitka spruce on the Queen Charlotte Islands. Can. Dept. Agr. Tech. Bul. 56:1-35.

2. DENYER, W. B. G. and RILEY, C. G. 1954. Interim report, decay of white spruce in the Prairie Provinces. Can. Dept. Agr. Forest Biol. Div. Mimeographed. Saskatoon.

3. ETHERIDGE, D. E. 1954. Interim report on the decay of subalpine spruce on the Rocky Mountain Forest Reserve in Albert2. Can. Dept. Agr. Forest Biol. Div. Mimeographed. Calgary.

4. ETHERIDGE, D. E. Decay in subalpine spruce on the Rocky Mountain Porest Reserve in Alberta. Ms.

5. HEPTING, G. H. and ROTH, E. R. 1950. The fruiting of heart rot fungi on felled trees. J. Forestry, 48:332-333.

6. NORDIN, VIDAR J. 1954. Studies in forest pathology. XIII. Decay in sugar maple in the Ottawa-Huron and Algoma Extension Forest Region of Ontario. Can. J. Botany, $32: 221-258$.

7. NORDIN, VIDAR J. 1954. Forest pathology in relation to the management of lodgepole pine in Alberta. For. Chron. 30:209-306.

8. Rocky Mountain Section, Canadian Institute of Forestry. 1955. Forest fire protection in Alberta, review and recommendations. Calgary.

9. WAGENER, WILLIS W. and DAVIDSON, ROSS W. 1954. Heart rots in living trees. Bot. Review, XX:61-134.

10. ZILLGITT, W. R. and GEVORKIANTZ, S. R. 1948. Estimating cull in northern hardwoods and with special reference to sugar maple. J. Forestry, 46:588-594. 
FIGURES FOR PRECEDING PAPER BY V. J. NORDIN
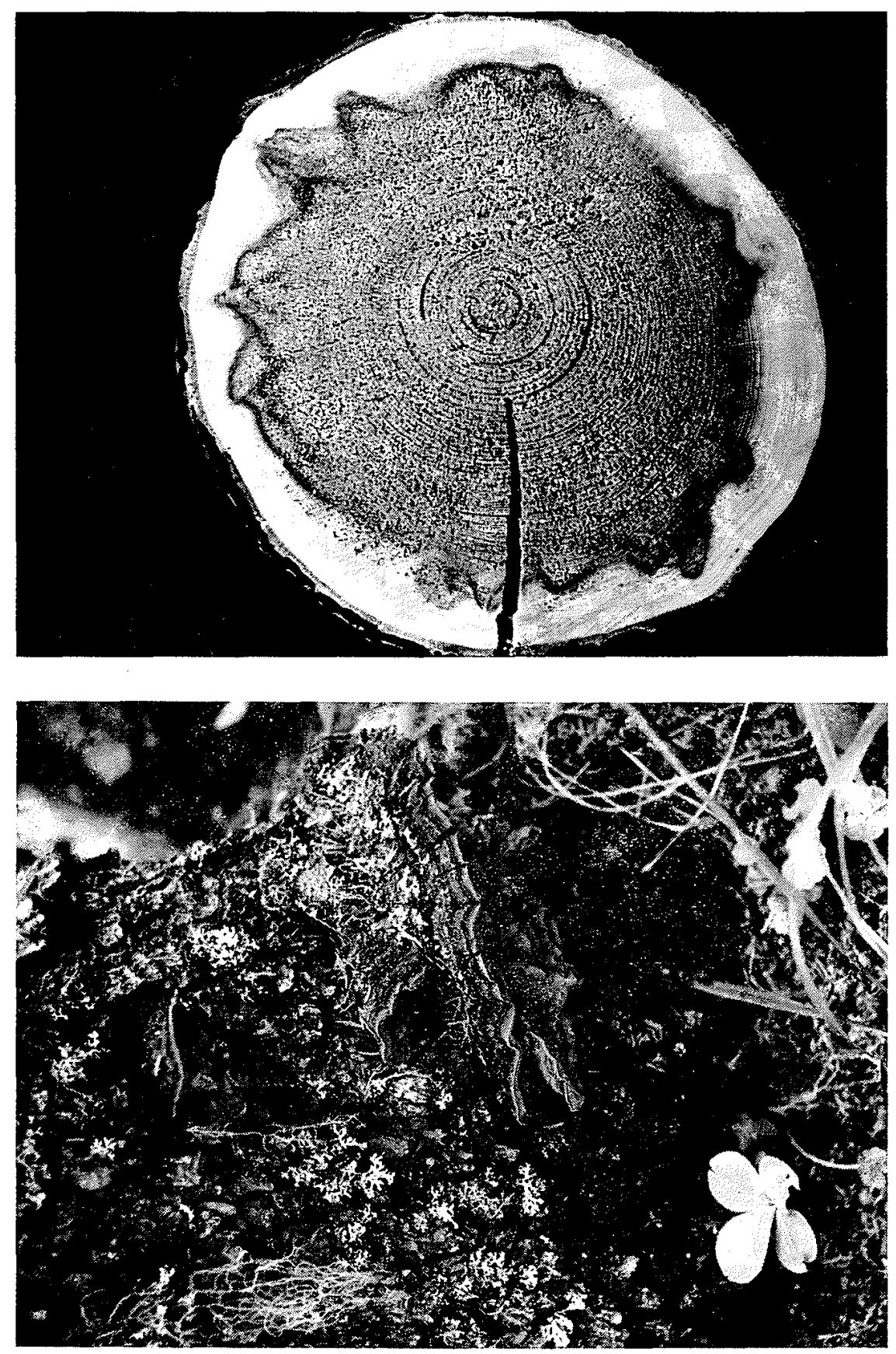
FIGURES FOR FOLLOWING PAPER BY ERIK JORGENSEN
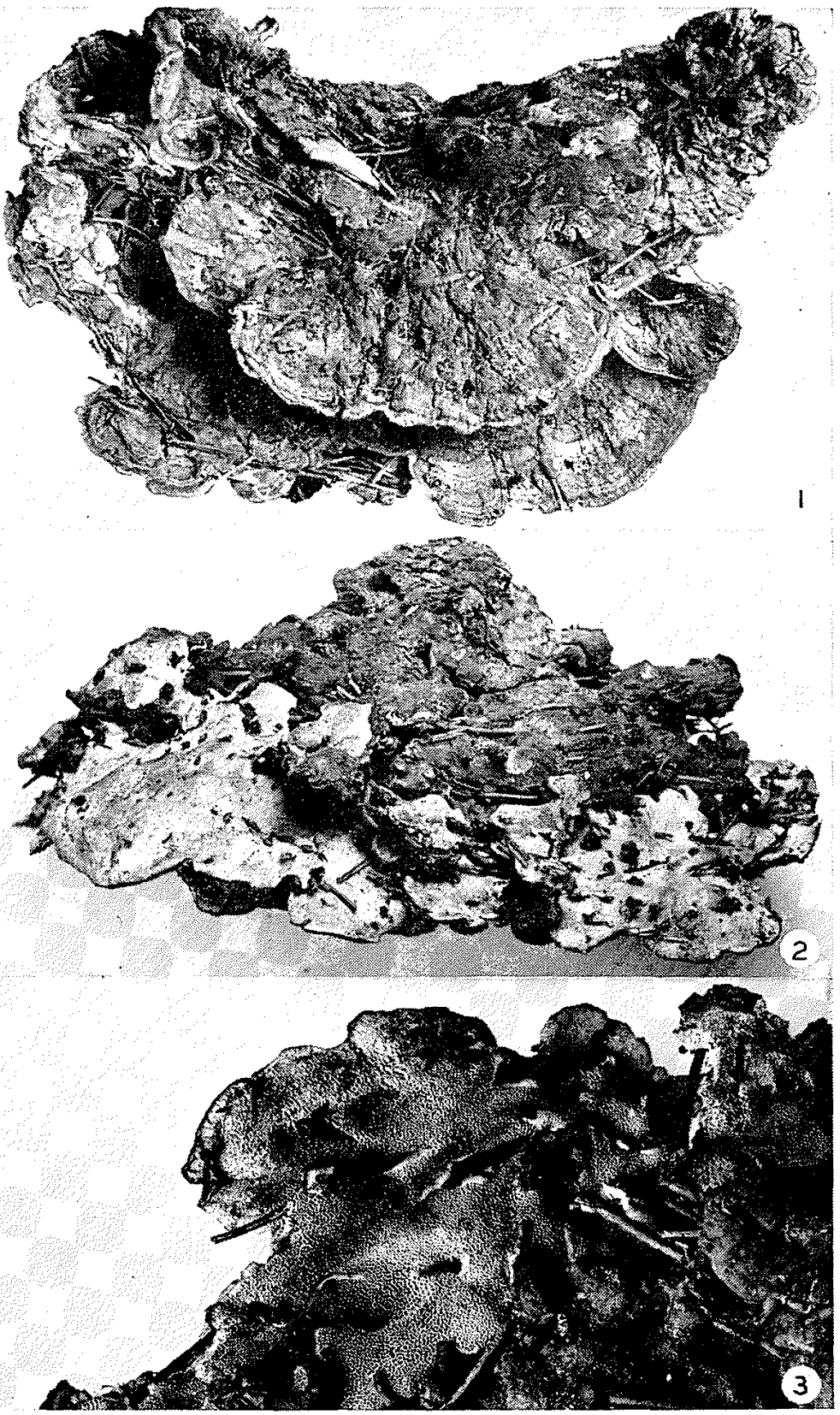

PLATE I

Photo Miss J. F. Robinson

Fruit body of $F$. annosus from St. Williams, Ontario.

Figure 1. Viewed from above. Figure 3. Enlarged section of the poroid surface. 